Doi: HTTPS://DOI.ORG/10.23910/IJBSM/2018.9.1.3C0599

\title{
Ichthyofaunal Diversity of Dol net fishery at Navabandar, Gujarat
}

\author{
K. M. Sikotaria, G. S. Temkar, , P. Abdul Azeez and K. L. Mathew
}

College of Fisheries Science, Junagadh Agricultural University (JAU), Veraval, Gujarat (362 265), India

\section{Corresponding Author}

G. S. Temkar

e-mail: temkarganesh1990@gmail.com

\author{
Article History \\ Article ID: 3C0599 \\ Received in $26^{\text {th }}$ October, 2017 \\ Received in revised form $17^{\text {th }}$ December, 2017 \\ Accepted in final form $21^{\text {st }}$ January, 2018
}

\begin{abstract}
Dolnetters contributed significantly to the fish production in Gujarat. However, dol net fishermen usually live in poverty threshold. Available secondary data suggests that overfishing prevails in Indian marine sector. While considering the complexity of dol net operations and the importance of fishery along North West coast of India present study done along one of the major dol net landing center of Gujarat. Study conducted to estimate the commercially important ictyofaunal diversity landed along Navabandar coast, Gujarat during the period from $15^{\text {th }}$ August 2012 to $31^{\text {st }}$ April 2013 (one fishing season). The present study revealed that altogether 24 major fish and shellfish species caught by $\mathrm{dol}$ net along Navabandar coast. There were 312 dolnetters in Navabandar fishing village. There was good variety of marine resource landing observed in dol net fishery. Non-penaeid shrimps contributed $40.22 \%$ of the total landings, followed by Harpadon nehereus (Bombay duck; 15\%). Amongst the landed species, six were pelagic while 16 were demersal and the remaining two were miscellaneous (Non-penaeid shrimps). Demersal fishes contributed maximum (66\%) to the total catch with contribution of about $72 \%$ to the total revenue. Sciaenids and pomfrets were the major as economically important species. Jaw fish fetched the maximum revenue (32\%). Therefore, present study concluded that $\mathrm{dol}$ net fishery supported considerable variation in species composition. Study also revealed that due to usage of small mesh size there was sign of overfishing reported, so management policies must need to implement for conservation of marine fisheries resources for fulfilling present and future needs.
\end{abstract}

Keywords: Ictyofaunal diversity, Dol net, Navabandar, Gujarat

\section{Introduction}

Dol netting is a very popular passive technique of fishing practiced from early years. This net is an indigenous version of bag net operated along the northwest coast of India. Bombay duck, Harpadon nehereus (Ham) is the main catch at Navabandar situated along Saurashtra coast, Gujarat; contributing about $97 \%$ of the total landings of Bombay duck in India (Jhingran, 1982). Consequently, dol net fishery has become synonymous with Bombay duck fishery. The report along Navabandar, Rajpara and Jaffrabad coasts of Saurashtra stated Bombay duck landing contributed of around $31.12 \%$ to total dol net landings (Ghosh et al., 2009). The contribution of catch due to dol net has been $8.5 \%$ and $9.7 \%$ during 2005 and 2006 respectively (Srinivasan et al., 2009). This study has also revealed that the contribution of the mechanized dol net has been significant in both the years of study with 30\% (194000 tonnes) and $31 \%$ (264000 t) during 2005 and 2006 respectively. The fishery of $d o l$ net has exhibited a significant increase in the production over the years due to an increase in the fishing efforts and mechanization leading to a simultaneous increase in the rate of catch (Mohanraj et al., 2009). Some of the other studies reported that the dominating species of $\mathrm{dol}$ net catch along the northwest coast include Bombay duck, clupeids, elasmobranches, catfishes, croakers, eels, ribbon fishes, threadfins, pomfrets, flat fishes, penaeid shrimps, non-penaeid shrimps, lobsters, etc (Sehara and Karbhari, 1987; Jadhav and Josekutty 2007; Jaydev et al., 2007). Umesh and Sujit (2007) has observed huge landings of the catfish $A$. dussumieri along Gujarat coast by a Karli dolnetter.

Gujarat has the longest coastline in the country $(1600 \mathrm{~km}$; comprising of $19.71 \%$ ). The contribution of marine fish catch from Saurashtra has always formed the major share from the state of Gujarat. However, Saurashtra has around 53\% coastline of the state, its contribution in terms of marine fish landings amounts to $90 \%$. Dol nets are operated mainly in three regions in Gujarat, viz., Umbergaon to Kavi (along the Southern Gujarat), Siyalbet to Diu (along the Saurashtra coast) and Takkara to Modhwa (in the Gulf of Kachchh region). Saurashtra region considered as the most important among these three regions, as it has fishing centers at Jaffarabad, Rajpara, Navabandar and Goghla (Manojkumar and Dineshbabu, 1999). Navabandar is one of the important marine fish-landing centers, which has contributed 10,634 $\mathrm{t}(1.54 \%)$ fish production in 2010-11 (Anon, 2012). Fishing 
operations continues throughout the month without any break at Navabandar. Fishing is the main occupation of the residents of this coastal village. About 1395 fishermen families are engaged in fishing and fishery allied activities (CMFRI, 2010).

\section{Materials and Methods}

\subsection{Study area}

Navabandar fishing village is located in the Junagadh district of Gujarat, a maritime state situated on the west coast of India. This village situated about $10 \mathrm{~km}$ away from Una taluka headquarter.

\subsection{Sampling unit}

The dolnetters operating along Navabandar coast were the sampling units for the present study. Information regarding the diversity of the landed species of fish along with the catch composition data of 20 dolnetters was collected at fortnightly intervals from randomly selected fishermen of Navabandar fish landing centre.

\subsection{Sampling procedure}

Fishing season in Gujarat is of nine months i.e., from September to May. The data for the study were collected from $15^{\text {th }}$ August 2012 to $31^{\text {st }}$ April 2013, which considered as one fishing season. Catch composition data recorded at fortnightly interval from 20 dolnetters as described by Sehara and Karbhari (1987). Dolnetters selected randomly on the first come first select basis.

\section{Results and Discussion}

Dol net fishery of Navabandar coast comprised of Bombay duck, ribbonfish, crockers, seerfish, sole fish, catfish, shark, silver pomfret, thread fin, rays, clupeids, reef cod, eel, squid, penaeid shrimps and non-penaeid shrimps. Apart from these, several other species were also caught, but in lesser quantity.

\subsection{Bombay duck}

Bombay duck invariably dominated the dol net catch. It formed about $15 \%$ of the total catch during the period of study. The main species of Bombay duck was Harpadon nehereus. It was caught almost throughout the year i.e., from August to April. Its maximum catch was in August (51\%) and the lowest in February (about 1\%), contributing about $44 \%$ of the total pelagic fish landings (Plate 1).

\subsection{Seerfish}

Seefish contributed less than one per cent to the total catch. The major species of seerfish caught was Spotted seerfish (Scomberomorus guttatus). The quantity of its catch was the highest in November (22\%) whereas it was the lowest in January (less than one per cent). It contributed about $1 \%$ of the total pelagic fish landings (Plate 1).

\subsection{Ribbonfish}

Ribbonfish contributed about $15 \%$ to the total catch. The major species of ribbonfish found in the catch was Silver

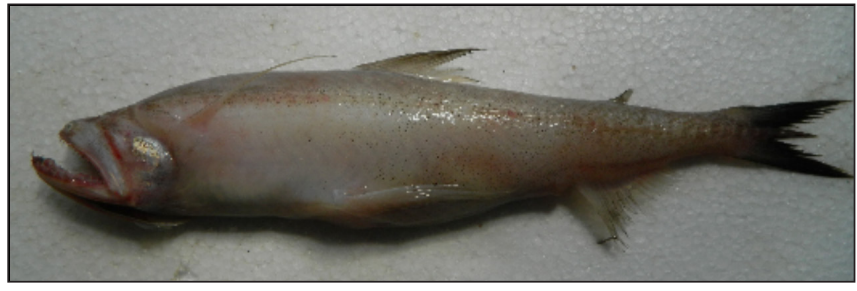

a. Bombay duck (Harpadon nehereus)

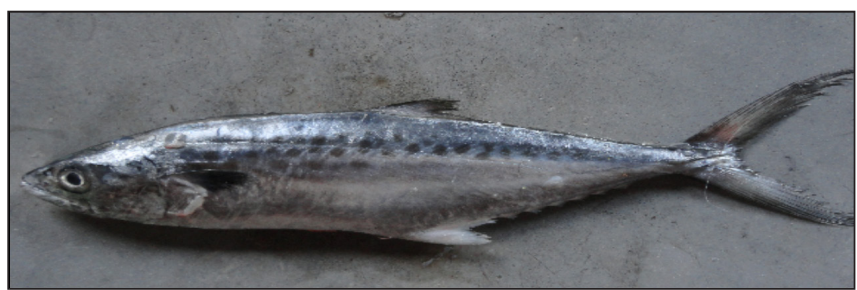

b. Seerfish (Scomberomorus guttatus)

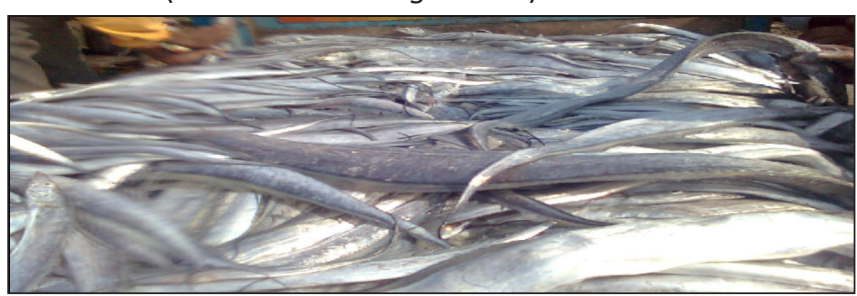

c. Ribbonfish (Lapturecanthus savala)

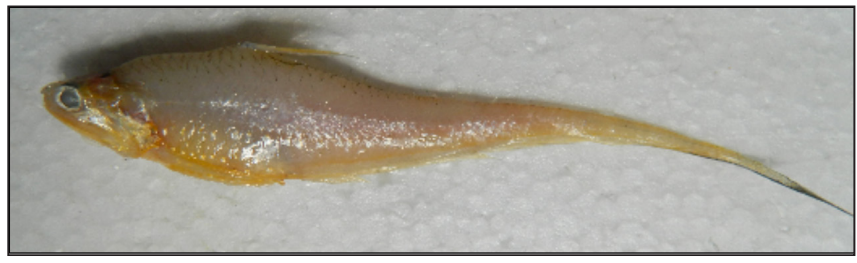

d. Golden anchovy (Colia dussumieri)

Plate 1: Major species caught by do/ net at Navabandar coast ribbonfish (Lapturecanthus savala). It was available almost throughout the year i.e., from August to April. The quantity of its catch was the highest in August (53\%) whereas it was the lowest in March (less than one per cent). Its contribution to total pelagic fish landings was about $44 \%$ (Plate 1 ).

\subsection{Clupeids}

The fishery of clupeids was fairly good at Navabandar. This group comprised mainly of two species; the commonest being Golden anchovy (Colia dussumieri) and the other being Big eye ilisha (Ilisha megalaptera). These groups formed about $3 \%$ of the total dol net fishery. Golden anchovy contributed about $2 \%$ while Big eye ilisha contributed only less than one per cent to the total catch (Plates 1 and 2).

\subsection{Carangids}

Carangids contributed less than one per cent to the total catch. The major carangid caught was Talang queenfish (Scomberoides commesonnianus). The catch of carangids was the highest in November (27\%) whereas it was the lowest in April (6\%; Plate 2).

\subsection{Sciaenids}

Sciaenids formed the major demersal fishery at Navabandar. 


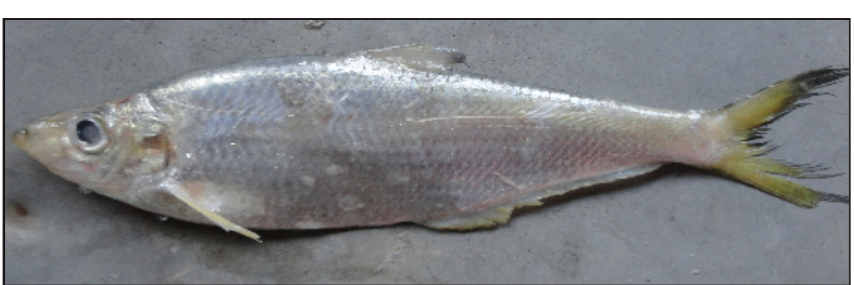

a. Big eye ilisha (Ilisha megaloptera)

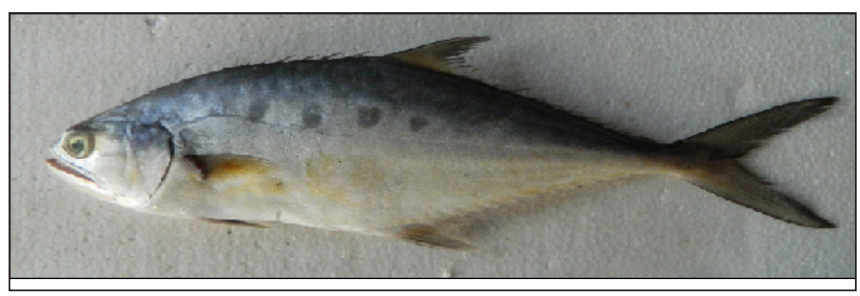

b. Talang queenfish (Scomberoides commesonnianus)

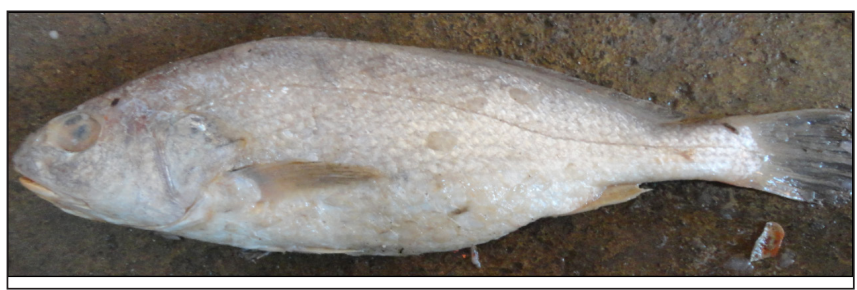

c. Bearded crocker (Johnius dussumieri)

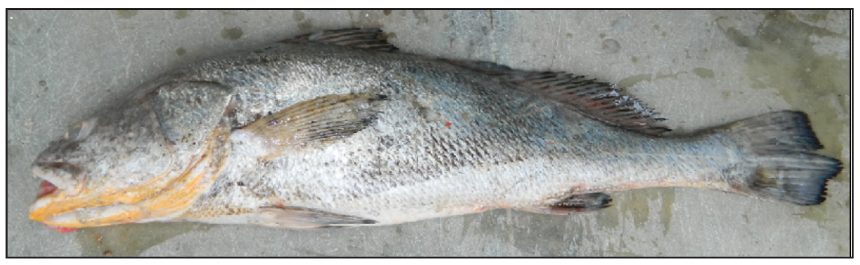

d. Jew fish (Protonibea diacanthus)

Plate 2: Major species caught by do/ net at Navabandar coast

Economically this group was very important. It comprised mainly of three species viz., Bearded crocker (Johnius dussumieri), Jew fish (Protonibea diacanthus) and Bronge crocker (Otolithoides biauritus). They were caught almost throughout the fishing season i.e., from August to April. These species constituted about $8 \%$ of the total dol net fishery. Bearded crocker contributed about $4 \%$, Jew Fish $2 \%$ and Bronge crocker contributed $3 \%$ of the total catch. Sciaenids contributed $32 \%$ of the total demersal fish landings (Plates $2 \& 3)$.

\subsection{Threadfin}

Threadfins contributed only less than one per cent to the total catch during the period of study. The major species of threadfin caught was Indian threadfin (Polynemus indicus). The catch of the group reached the highest level in October (21\%) whereas it was the lowest in February (9\%; Plate 3).

\subsection{Pomfret}

Pomfret is the most sought fish for financial returns and gourmand needs. It contributed about one per cent to total catch. The major species of pomfret caught was Silver pomfret (Pampus argentius). Its maximum catch was in August (69\%) whereas it was the lowest in February (2\%; Plate 3).

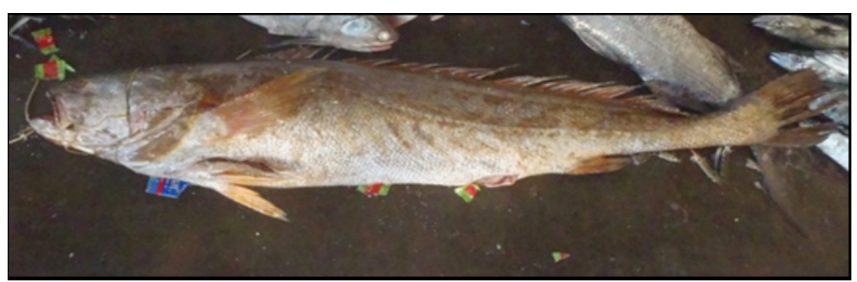

a. Bronge crocker (Otolithes biauritus)

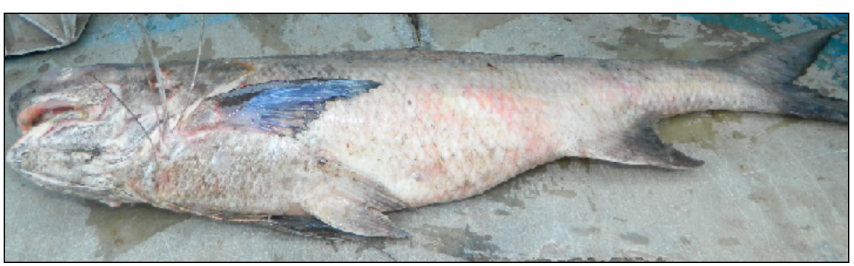

b. Indian threadfin (Polynemus indicus)

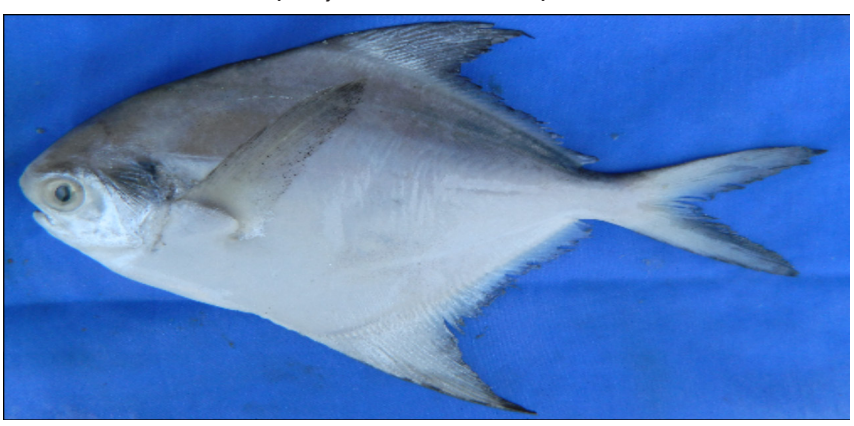

c. Silver pomfret (Pampus argenteus)

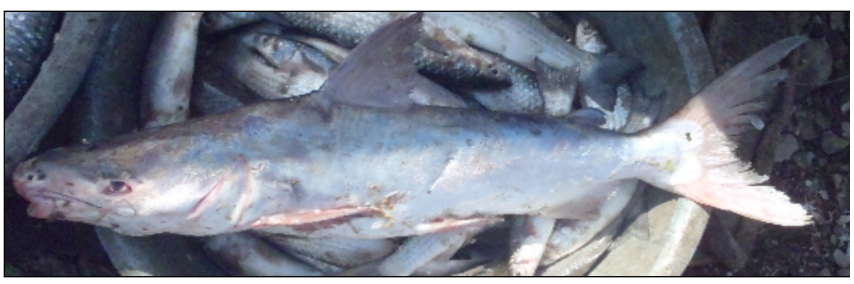

d. Catfish (Arius dussumieri)

Plate 3: Major species caught by do/ net at Navabandar coast

\subsection{Catfish}

Catfishes were one of the important demersal fishes caught in $\mathrm{dol}$ net. They contributed about $4 \%$ to the total catch during the study period. They were caught almost throughout the season i.e., from August to April. The major species of catfish caught was Dussumieri catfish (Arius dussumieri). The catch was the highest in April (22\%) whereas it was the lowest in January (3\%). It contributed about $14 \%$ of the total demersal fish landings (Plate 3 ).

\subsection{Reef cod}

The contribution of Reef cod to total catch during study period was less than one per cent. It was caught only in winter months. Six barred reef cod (Epinephus diacanthes) was the major species of reef cod caught off Navabandar.

\subsection{Sole fish}

Sole fish was one of the important demersal fish caught in dol 
net, contributing about $4 \%$ to the total catch. It caught almost throughout the fishing season i.e., from August to April. The major catch of Sole fish was (Cynoglossus macrolepidotous). Its highest catch was in August (25\%) whereas it was the lowest in April (2\%). Sole fish contributed about $16 \%$ to the total demersal fish landings (Plate 4).

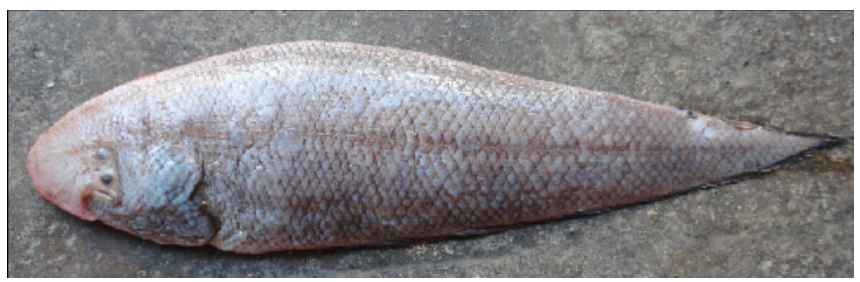

a. Sole fish (Cynoglossus macrolepidotus)

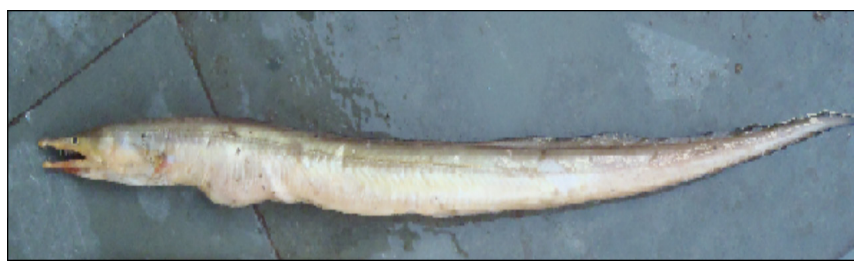

b. Indian pike conger (Conresox talbonoides)

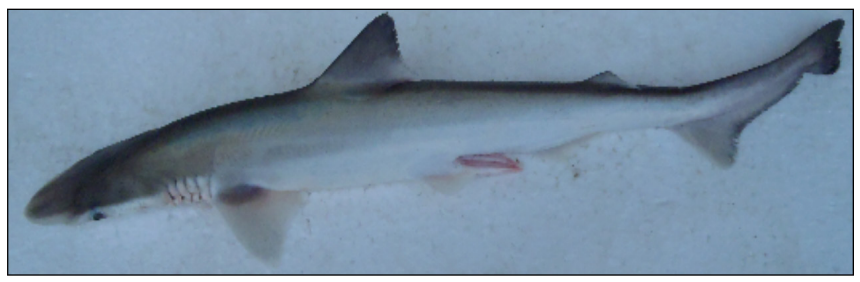

c. Shark (Scoliodon laticaudus)

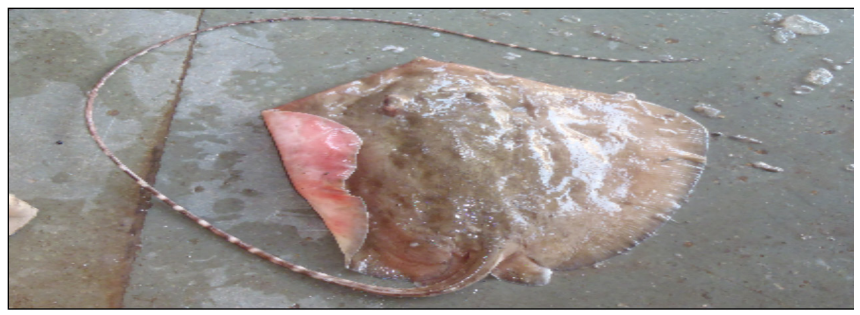

d. Ray (Dasyatis zugei)

Plate 4: Major species caught by do/ net at Navabandar coast

\subsection{Eel}

The contribution of eel to the total catch during the period of study was less than one per cent. It caught throughout the period of study, but in lesser quantities (Plate 4). Indian pike conger (Congresox talbonoides) was the major species of eel observed in the catch.

\subsection{Shark}

Sharks contributed less than one per cent to the total catch. Though it caught throughout the year, the quantity of catch was less (Plate 4). The major species of shark observed was Dog shark (Scoliodon laticaudus).

\subsection{Ray}

Rays also contributed less than one per cent to the total catch during study period (Plate 4). Pale-edged sting ray (Dasyatis zugei) was the major species of ray found in the catch.

\subsection{Cephalopods}

Cephalopods contributed about $0.55 \%$ to the total catch. Squid (Loligo duvaucelli) was the major species observed in the catch.

\subsection{Shrimps}

Penaeid shrimps were the major demersal fishery at Navabandar. Economically this group was very important. This group comprised mainly of four species viz., Kiddi prawn (Parapeneopsis stylifera), Indian prawn (Metapeneous affinis), Coastal mud prawn (S. crassicornis) and Indian white prawn (Penaeus spp.). They were caught almost throughout the year i.e., from August to April. These groups formed about $5 \%$ of the dol net fishery. Shrimps contributed $20 \%$ of the total demersal fish landings (Plate 5).

The major portion of $d o /$ net catch comprised of non-penaeid shrimps, which contributed about $40 \%$ to the total catch at Navabandar. Paste shrimp (Acetes indicus) and Hunter shrimp (Hippolysmata ensirostris) were the species observed in this category. Locally it known as Kuto, which considered under miscellaneous group due to their low market value. They were caught almost throughout the fishing season i.e., from August to April. Their maximum catches occurred in August

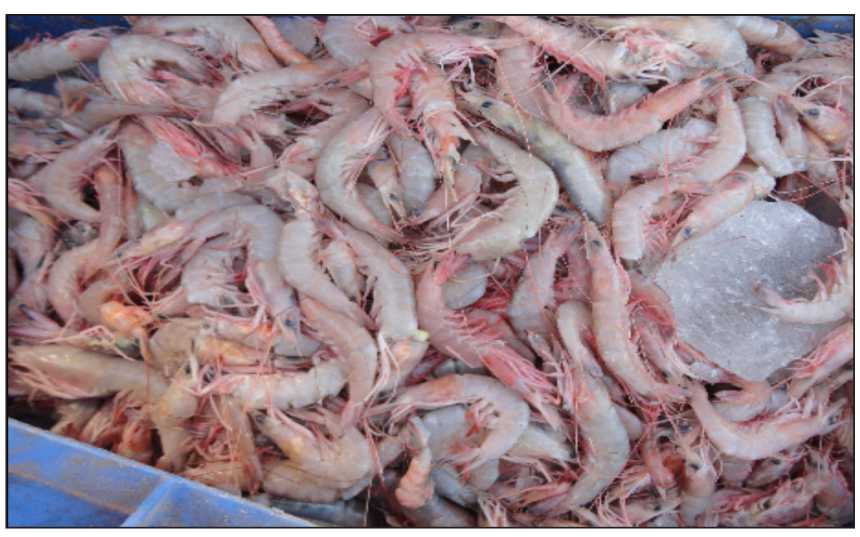

a. Shrimps

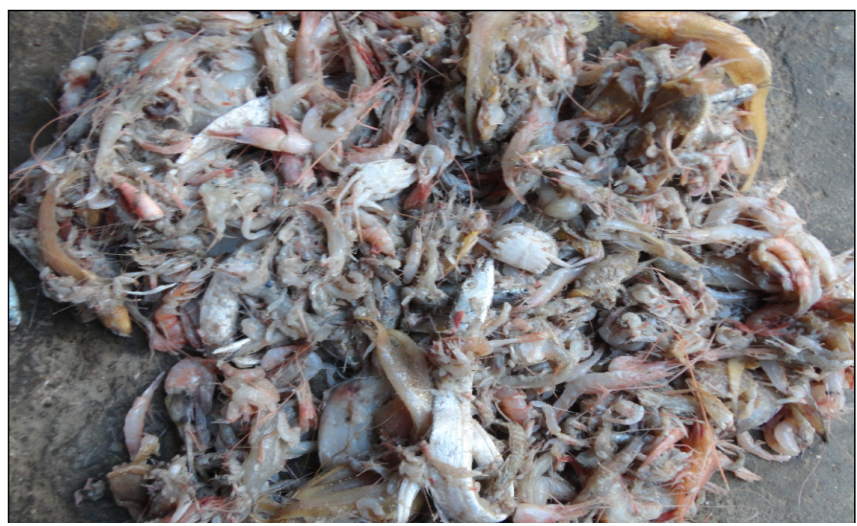

b. Miscellaneous (kuto)

Plate 5: Major species caught by dol net at Navabandar coast 
(23\%) whereas it was the lowest in January (6\%). Paste shrimp constituted the major portion of the non-penaeid shrimp (Plate 5).

The $d o l$ net operations at Versova during one peak season of two months (November and December 1974) revealed that the catch has comprised of Bombay duck (25\%), Coilia (20\%) and shrimps (35\%; Rao and Bindu, 1976). About 33 species caught by dol net fishery at Sasoon dock (Bombay; Pillai, 1981). Large quantities of small-sized Silver pomfret $P$. argenteus (Eupher) caught in dol net during 1979-80 and 1980-81 fishing seasons along Navabandar coast (Khan, 1984). The fishery of Bombay duck $H$. nehereus in Saurashtra waters has constituted about 68 to $77 \%$ of the dol net landings at Navabandar (Khan, 1985). The other important species have consisted of $C$. dussurnieri, ribbonfish, non-penaeid shrimp, viz., A. indicus, Nematopalaernon tenuipes and $H$. ensirostris. Penaeid shrimps, ghol, wam, pomfret and catfishes have also landed in considerable quantities at Navabandar.

Another study conducted at Sassoon Docks area has revealed unusual heavy landings of catfish by dol nets. The catch has consisted of only one species of catfish i.e., T. dussumieri (Waghmare, 1987). Dol net fishery reported as a multi species fishery comprising fishes, penaeid shrimps and nonpenaeid shrimps supporting almost $85 \%$ of the fisherman families at Versova, Bombay (Alexander and Narayan, 1992). Kizhakudan (2002) has reported the landing of Black porpoise Neophocaena phocaenoides and G. cuvier in dol net at Seemar, Gujarat. The catch of silver pomfret (89.51\%) has attained as the major one followed by Prastromateus niger, $P$. chinensis, seerfish, sharks, Chirocentrus dorab, catfish and kati, constituting $8-10 \%$ of the total landings (Chavan et al., 2004). A recent study on the catch composition of dol net along Saurashtra coast has revealed that it mainly consists of $H$. nehereus, $P$. diacanthus, penaeid prawns, non-penaeid prawns, $P$. argenteus, Trichiurus sp., carangids and catfishes (Nair et al., 2007). Thangavelu et al. (2010) have also observed an unusual heavy landing of the catfish $A$. dussumieri at Rajapara Bay of Gujarat coast.

\section{Conclusion}

$D o l$ net fishing of Navabandar village is a profitable vocation. Increased fishing efforts reports crafts improvement, which increases voyage period, causes heavy landings of certain commercially important species. This in future will causes overexploitation of fisheries resources. The study stated that because of smaller do/ net mesh size, small sized fishes caught in large quantities. To avoid such future concerns regarding collapsing of natural resource potential, certain fisheries management measures need to implement. Awareness among the fisherman community must require.

\section{Acknowledgement}

The authors thank Dr. A. Y. Desai, Dean and Principal, College of Fisheries, Veraval, Junagadh Agricultural University, Gujarat for granting permission to carry out the work. The authors are also grateful to Junagadh Agricultural University for granting permission to conduct this investigation as a part of the P.G. Research Programme during the course of master degree studies of the first author and for providing required facilities for the research works.

\section{References}

Alexander, K., Narayan, K.K., 1992. Stock assessment of Bombay duck Harpodon nehereus (Ham) off Maharashtra coast. Indian Journal of Fisheries 39, 243-248.

Anonymous, 2012. Gujarat Fisheries Statistics: 20102011. Commissioner of Fisheries, Govt. of Gujarat, Gandhinagar.

Chavan, B.B., Waghmare, K.B., Umesh, H.R., 2004. Unusual landing of silver pomfret, Pampus argenteus by karali dol net at Bassein Kolliwada (Vasai) landing centre, Thane district, Maharashtra. Marine Fisheries Information Service Technical and Extension Series 180, 20.

CMFRI, 2010. Marine Fisheries Census 2010 Gujarat. Published by Central Marine Fisheries Research Institute, Cochin, 19-22.

Ghosh, S., Pillai, N.G.K., Dhokia, H.K., 2009. Fishery and population dynamics of Harpadon nehereus (Ham.) off the Saurashtra coast. Indian Journal of Fisheries 56(1), 13-19.

Jadhav, D.G., Josekutty, C.J., 2007. On an unusual heavy landing of Koth, Otolithoides biauritus (Cantor, 1850) at Arnala, Thane, Maharashtra. Marine Fisheries Information Service Technical and Extension Series 194, 20.

Jaydev, H., Sujit, S., Josekutty, C.G., Jadhav, D.G., Thakurdas, U.H.R., 2007. A note on the recurring heavy catch of 'Ghol' Protonibea diacanthus by dol net at Bassien koliwada, Maharashtra. Bulletin of Central Marine Fisheries Research Institute 191, 24-25.

Jhingran, V.G., 1982. Fish and Fisheries of India. Hindustan Publishing Corporation (India) Delhi, 545.

Khan, Z.M., 1984. A probable nursery ground of silver pomfret $P$. argenteus (Eupher) off Navabandar (Gujarat). Central Marine Fisheries Research Institute, 257-260.

Khan, Z.M., 1985. Observation on the fishery of Bombay duck, Harpodon nehereus (Ham.) along the Saurashtra coast. Indian Journal of Fisheries 32, 431-438.

Kizhakudan, J.K., 2002. On a black porpoise Neophocaena phocaenoides, G. cuvier landed in dol net at Seemar, Gujarat. Bulletin of Central Marine Fisheries Research Institute 173, 7.

Manojkumar, B., Dineshbabu, A.P., 1999. Dol net fisheries of the Saurashtra coast. Bulletin of Central Marine Fisheries Research Institute 161, 1-8.

Mohanraj, G., Nair, K.V.S., Asokan, P.K., Ghosh, S., 2009. Status of marine fisheries in Gujarat with strategies for sustainable and responsible fisheries. Asian Fisheries 
Science 22, 285-296.

Nair, K.V.S., Chakraborty, R.D., Savaria, Y.D., Polara, J.P., Dhokia, H.K., Thumber, B.P., 2007. Catfish fishery by dolnetters along the Saurashtra coast. Marine Fisheries Information Service Technical and Extension Series pp. 193.

Pillai, S.K., 1981. Some Observations on Dol (Bag) Net Fishery at Sassoon Dock, Bombay. Journal of the Bombay Natural History Society 80, 331-340.

Rao, P.S., Bindu, S.T., 1976. Costs and Earning of dol net operation at Versova during peak season. Journal of Indian Fisheries Association 6, 38-48.

Sehara, D.B.S., Karbhari, J.P., 1987. A study on 'Dol' net fishery at selected Centers in North-West coast with special reference to costs and retunes. Bulletin of Central Marine Fisheries Research Institute 78, 1-15.
Srinivasan, J., Ammini, P.L., Ramani, K., Najeemudeen, S.H., 2009. An overview of marine fish landings in India during 2005-2006. Marine Fisheries Information Service Technical and Extension Series No. 202.

Thangavelu, R., Ghosh, S., Mohammed, G., Zala, M.S., Polara, J.P., Dhokia, H.K., Bhint, H.M., 2010. Unusual heavy landings of the catfish Arius dussumieri in Rajapara Bay of Gujarat coast. Marine Fisheries Information Service Technical and Extension Series 206, 9-11.

Umesh, R., Sujit, S., 2007. Unusual landings of Arius dussumieri by Karli dol net at Bassien Koliwada. Bulletin of Central Marine Fisheries Research Institute 191, 26-27.

Waghmare, K.B., 1987. Heavy landings of Cat fish by 'Dol' nets at Sassoon docks. Marine Fisheries Information Service Technical and Extension Series 78, 21. 